\title{
Karakterisasi Protein Alga Coklat dan Merah dari Perairan Pulau Pari Sebagai Zat Antioksidan
}

\author{
Elvi Kustiyah ${ }^{1}$, Bungaran Saing ${ }^{2}$, Avira Afriyanti ${ }^{3}$, Ibnu Susanto Joyosemito ${ }^{4}$ \\ 1,2,3 Program Studi Teknik Kimia, Fakultas Teknik, Universitas Bhayangkara Jakarta Raya \\ ${ }^{4}$ Program Studi Teknik Lingkungan, Fakultas Teknik, Universitas Bhayangkara Jakarta Raya \\ Email: elvikustiyah@gmailcom
}

\begin{abstract}
ABSTRAK
Kandungan dalam alga meliputi polisakarida, mineral, protein, lemak, vitamin, polifenol dan senyawa bioaktif yang bisa memberikan manfaat terhadap sumber makanan, vitamin maupun pharmasi. Investigasi karakter Alga Coklat dan Alga Merah yang diperoleh dari perairan pulau pari kepulauan seribu wilayah Indonesia dilakukan dengan tujuan untuk mendapatkan zat yang mampu menjadi alternatif sumber anti oksidan. Metode yang digunakan dalam penelitian ini adalah ekstraksi maserasi dengan pelarut Phosfat Buffer Saline (PBS) sedangkan Uji kadar protein alga menggunakan metode Lowry dan uji aktivitas antioksidan menggunakan metode 1,1-Diphenyl-2-Pycrylhydrazy(DPPH). Hasil penelitian menunjukkan kadar protein yang tertinggi diperoleh pada sampel alga merah, sedangkan nilai kadar protein paling rendah terdapat pada alga cokelat. Nilai aktivitas antioksidan yang paling baik yaitu pada sampel yang berasal dari alga merah dengan nilai $I_{50}$ sebesar 3,5421 mg/ml.
\end{abstract}

Kata Kunci: Alga, protein, antioksidan.

\section{ABSTRACT}

An alga contains polysaccharides, minerals, proteins, fats, vitamins, polyphenols and bioactive compounds that can provide benefits for food, vitamin and pharmaceutical sources. Characteristic investigations of Brown Algae and Red Algae from the Pari Island waters, Thousand Islands, Indonesia, were carried out to obtain substances that could be an alternative source of antioxidants. The maceration extraction method using Phosphate Buffered Saline (PBS) as solvent was used in this study. Protein content in algae was investigated by Lowry method and the 1,1-diphenyl-2-picrylhydrazyl (DPPH) method was used to investigate the antioxidant activity of algae The results showed that the highest protein content was found in Red Algae and the lowest is in Brown Algae. The best value of antioxidant activity was found in Red Algae with the IC50 value of $3.5421 \mathrm{mg} / \mathrm{ml}$.

Keywords: Algae, protein, antioxidants. 


\section{PENDAhULUAN}

Antioksidan adalah salah satu parameter penting untuk memantau kesehatan tubuh manusia, yaitu dengan cara mengendalikan reaktivitas yang tinggi dari radikal bebas. Akibat buruk dari radikal bebas ini adalah mampu mempengaruhi membran dan inti sel sehingga mampu merusak dirinya sendiri.(Ito et al., 2018) Adapun sel yang sering diserang radikal bebas adalah sel lemak, sel protein dan sel asam nukleat. Salah satu mekanisme pertahanan tubuh terhadap serangan radikal bebas adalah zat antioksidan(Amarowicz, Pegg, Rahimi-Moghaddam, Barl, \& Weil, 2004)

Zat antioksidan banyak ditemukan di makanan yang mengandung vitamin $\mathrm{A}$, vitamin $\mathrm{C}$, vitamin $\mathrm{E}$, selenium, beta karoten, lutein dan lignan. Antioksidant biasanya terkandung pada buah-buahan, sayursayuran, bawang-bawangan juga bisa didaptkan dari biota laut. Penelitian telah banyak dilakukan untuk menginvestigasi aktivitas anti oksidan di timun laut, bintang laut, selada laut bahkan juga rumput laut atau kelompok algae.(Dang, Bowyer, Van Altena, \& Scarlett, 2017)

Keanekaragaman jenis dan kelimpahan alga di Indonesia merupakan terbesar dibandingkan dengan negara lain. Namun, pemanfaatan alga di bidang industri dan kesehatan masih belum optimal. Ironisnya, di Indonesia, makroalga (rumput laut) hanya dibiarkan sebagai sampah lautan, mengapung, hanyut terbawa arus, ataupun terdampar di pinggir pantai. Padahal alga berpotensi ekonomis sebagai bahan baku dalam industri dan kesehatan dibalik peran alga yang bertugas menjaga kestabilan ekosistem laut dan tempat hidup serta tempat berlindung bagi biota laut lain(Dang et al., 2017)

Makroalga merupakan tumbuhan laut yang secara morfologis tidak dapat dibedakan antara akar, batang dan daun secara jelas. Seluruh tubuh rumput laut hanya menyerupai batang yang disebut thallus. Klasifikasi rumput laut berdasarkan kandungan pigmen terdiri dari 4 kelas, yaitu rumput laut hijau (Chlorophyta), rumput laut merah (Rhodophyta), rumput laut coklat (Phaeophyta) dan rumput laut pirang (Chrysophyta) . (Wang, Xiao, Wang, Zhou, \& Tang, 2007). Dalam rumput laut mengandung polisakarida, mineral, protein, lipid dan lemak, vitamin, polifenol dan senyawa bioaktif. Alga mempunyai beragam potensi bioaktivitas antara lain sebagai obat dan suplemen, antioksidan, antiobesitas (pelangsing), antidiabetes, antibakteri, antiinflamasi, dan antikanker (Suparmi \& Sahri, 2009).

Protein merupakan makromolekul dalam sel yang mempunyai berat molekul besar yang sangat bervariasi.(Liu, Jin, Lin, Jones, \& Chen, 2015) Struktur protein terdiri dari polipeptida yang mempunyai rantai panjang, dan tersusun atas banyak asam amino. Protein memiliki peranan penting dalam semua proses biologi. Peran dan aktivitas protein antara lain: katalis enzimatik, transport dan penyimpanan, koordinasi gerak, penunjang mekanis dan protein imun. Pada rumput laut jenis coklat, protein yang terkandung di dalamnya berkisar $5-15 \%$ dari berat kering, sedangkan pada rumput laut hijau dan merah berkisar 10-30\% dari berat kering (Suparmi \& Sahri, 2009).

Penelitian ini bertujuan untuk mengetahui nilai kuantitas kadar protein yang terdapat dalam alga coklat dan Alga Merah serta potensinya sebagai zat antioksidan yang diambil dari pantai di Kepulauan Seribu. Penelitian ini dilakukan serangkaian tahapan pengerjaan, dimulai dari pengambilan sampel, ekstraksi protein, uji kadar protein alga, dan uji aktivitas antioksidan. 


\section{METODE PENELITIAN}

\subsection{Bahan}

Bahan utama yang digunakan dalam penelitian ini antara lain alga coklat dan Alga Merah yang berasal dari Perairan Pantai Pulau Pari Kepulauan Seribu. Sedangkan bahan-bahan pendukung yang digunakan antara lain: Phosphat Buffer Saline (PBS) $(0,02 \mathrm{M} ; \mathrm{pH} 7,0 ; 0,85 \% \mathrm{NaCl})$, Bovine Serum Albumin(BSA), akuades, Lowry A (follin clocalteus (Larutan asam phosphotungstat-phosphomolybdat) dengan akuades 1:1), Lowry B (Na2CO3 2\%; $\mathrm{NaOH} \mathrm{0,1} \mathrm{N;} \mathrm{CuSO4.5H2O} \mathrm{1 \% ,} \mathrm{Natrium} \mathrm{kalium} \mathrm{tartrat}$ 2\%), HCl $1 \mathrm{M}$, diphenylpicrylhydrazyl(DPPH), methanol, dan quarsetin

\subsection{Alat}

Alat yang digunakan dalam penelitian ini antara lain: plastic clip, spektrofotometer UV-Vis Hitachi U2000, neraca analitik, ice dryer, Sentrifugen Universal 320R, magnetik stirrer, refrigerator, pisau, blender, cawan kaca, stopwatch, kantong dialisis, saringan/kain kasa, gelas kimia, labu ukur, tabung reaksi, erlenmeyer dan pipet tetes

\subsection{Metode penelitian}

\subsubsection{Sampling Alga}

Alga yang sudah didaptakan dari perairan kepulauan seribu kemudian dicuci dengan air tawar untuk menghilangkan kotoran dan organisme yang menempel, kemudian alga dimasukkan kedalam kantong sampel dan diberi label. Kantong sampel dimasukkan ke dalam cool box yang berisi es untuk menjaga kesegarannya dan terhindar dari matahari secara langsung.

\subsubsection{Ekstraksi Protein}

Metode yang digunakan untuk mengekstraksi alga adalah metode maserasi dengan mengunakan pelarut Phosfat Buffer Saline (PBS). Sampel dari dalam cold storage dikeringkan dan dipotong kecilkecil dan dihaluskan, diambil sebanyak 10 gram dimasukkan ke dalam erlenmeyer. Sampel direndam dalam larutan Phosphat buffer saline (PBS) $60 \mathrm{ml}$ dan diaduk. Kemudian sampel dimasukkan ke dalam botol dan disimpan ke dalam refrigerator selama 24 jam pada temperatur $4^{\circ} \mathrm{C}$. Campuran sampel kemudian disaring dengan menggunakan kain kasa untuk mendapatkan filtrat. Filtrat yang diperoleh disentrifus dengan kecepatan 1000 rpm selama 15 menit pada temperatur $4{ }^{\circ} \mathrm{C}$. Supernatan hasil sentrifus ditambahkan larutan PBS sampai volume menjadi $100 \mathrm{ml}$ kemudian disimpan kembali ke dalam refrigerator.

\subsubsection{Uji Kadar Protein Total}

Kadar protein pada tiap fraksi ditentukan oleh metode Lowry menggunakan larutan standar Bovine Serum Albumin (BSA). Pertama, masukkan ke dalam tabung reaksi : 0(blanko) ;0,1;0,2;0,4;0,6 dan $1 \mathrm{ml}$ larutan protein standar (BSA), tambahkan air sampai volume total masing-masing $4 \mathrm{ml}$. Kemudian tambahkan 5,5 ml larutan Lowry B ke dalam masing-masing tabung, kocok, biarkan selama 10-15 menit. Setelah itu, tambahkan 0,5 ml larutan Lowry A, kocok hingga merata dengan cepat sesudah penambahan, biarkan selama \pm 30 menit sampai warna biru terbentuk. Lalu ukur absorbansinya pada panjang gelombang $650 \mathrm{~nm}$. Kemudian buat kurva protein standart. Hitung kadar tiap sampel dengan menggunakan persamaan yang didapat dari kurva protein standart. 


\subsubsection{Uji Aktivitas Antioksidan}

Uji kadar antioksidan menggunakan metode (DPPH). Sampel protein sebanyak $5 \mathrm{ml}$ dimasukan ke dalam cawan kaca dan dikeringkan dalam drying oven pada suhu $50^{\circ} \mathrm{C}$ selama 24 jam. Sampel kering yang didapat ditimbang kemudian dilarutkan dengan $1 \mathrm{ml}$ PBS . Larutan sampel tadi dimasukkan ke tabung reaksi dengan pengulangan 2 kali (duplo) sebanyak $4 \mathrm{ml}(1 \mathrm{ml}$ sampel $+3 \mathrm{ml}$ metanol). Blanko yang digunakan yaitu quarsetin. Kemudian tambahkan $1 \mathrm{ml}$ larutan DPPH $1 \mathrm{mM}$ sehingga konsentrasi larutan DPPH menjadi 0,2 mM. Sampel kemudian diinkubasi pada suhu ruang dan tempat yang gelap selama 30 menit. Setelah 30 menit, sampel diukur absorbansinya pada panjang gelombang maksimum $517 \mathrm{~nm}$. Pengukuran absorbansi kosong juga dilakukan.

\section{HASIL DAN PEMBAHASAN}

\subsection{Ekstraksi protein}

Ekstraksi yang dilakukan menggunakan metode maserasi, yaitu metode ekstraksi dengan cara merendam sampel dalam pelarut dengan atau tanpa pengadukan. Prinsip ekstraksi metode ini adalah pelarut akan menembus dinding sel dan masuk ke dalam sel yang mengandung komponen bioaktif. Proses perpindahan komponen bioakif dari dalam bahan ke pelarut terjadi secara difusi. Proses difusi merupakan perubahan secara spontan dari fase yang memiliki konsentrasi lebih tinggi menuju konsentrasi lebih rendah. Proses ini akan terus berlangsung selama komponen bahan padat yang dipisahkan menyebar diantara kedua fase. Proses difusi akan berakhir jika kedua fase berada dalam kesetimbangan, yaitu apabila seluruh zat sudah terlarut dan konsentrasi larutan yang terbentuk menjadi seragam. Pelarut yang digunakan adalah PBS pH 7,54. PBS sering digunakan dalam percobaan biologi untuk mempertahankan osmolaritas sel karena adanya ion garam $\left(\mathrm{Na}^{+}\right.$dan $\left.\mathrm{Cl}^{-}\right)$ yang mempertahankan $\mathrm{pH}$.

\subsection{Uji Kadar Protein Total}

Uji kadar protein total pada sampel alga coklat dan alga merah ditentukan menggunakan metode Lowry. Hasil pengujiannya menggunakan spektrofotometer balok ganda Hitachi U-2000 berukuran UV pada $650 \mathrm{~nm}$ dapat dilihat pada gambar 1 untuk kurva standard:

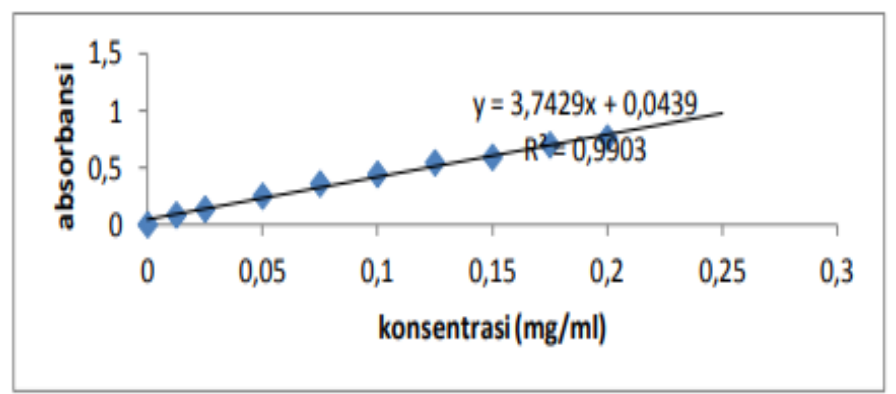

Gambar 1. untuk kurva standard pengukuran absorbasi alga merah dan alga coklat

Selanjutnya kurva standar ini digunakan untuk mendefiniskan kadar protein dalam sample 
Tabel 1. Kadar Protein Makroalga

\begin{tabular}{llc}
\hline Kode sampel & Sampel alga & \% Kadar protein $\mathbf{~ g} / \mathbf{1 0 g}$ \\
\hline S4 & Rhodophyta & $2,568 \pm 0,441$ \\
\hline S24 & Rhodophyta & $5,115 \pm 0,126$ \\
\hline S5 & Phaeophyta & $4,856 \pm 3,725$ \\
\hline S9 & Phaeophyta & $2,078 \pm 0,505$ \\
\hline
\end{tabular}

Tabel 1 menunjukkan bahwa kadar protein dalam alga sekitar 2-5\%. Kadar protein yang paling tinggi yaitu pada sampel S24 dengan kandungan sebesar 5,115 $\pm 0,126 \%$ yang berasal dari alga merah. Sedangkan nilai kadar protein paling rendah terdapat pada sampel S9 sebesar 2,078 $\pm 0,505 \%$ yang berasal dari alga cokelat. Temuan ini menunjukan bahwa makro alga Rhodophyta memiliki nilai protein yang lebih tinggi, dibandingkan dengan Phaeophyta.

\subsection{Uji Aktivitas Antioksidan}

Pengukuran aktivitas antioksidan yaitu dengan metode DPPH menggunakan spektrofotometri. Metode pengujian DPPH merupakan metode yang telah lama digunakan untuk penetapan aktivitas antioksidan. Hasil uji aktivitas antioksidan dinyatakan dalam \% aktivitas antioksidan yang ditunjukkan pada Tabel 2.

Tabel 2. Uji antioksidan activity dengan metode DPPH

\begin{tabular}{llccc}
\hline \multirow{2}{*}{ Sampel } & \multirow{2}{*}{ Jenis Alga } & \multicolumn{3}{c}{ \% Aktivitas Antioksidan } \\
\cline { 3 - 5 } & & $\mathbf{1 ~} \mathbf{~ m}$ & $\mathbf{2} \mathbf{~ m l}$ & $\mathbf{5}$ ml \\
\hline S4 & Rhodophyta & 21,8759 & 25,4886 & 37,2297 \\
\hline S24 & Rhodophyta & 3,5164 & 27,7909 & 62,8294 \\
\hline S5 & Phaeophyta & 20,8765 & 30,2932 & 35,4975 \\
\hline S9 & Phaeophyta & 1,9840 & 20,8765 & 58,3136 \\
\hline
\end{tabular}

Dari data pada Tabel 2 di atas, diperoleh persamaan regresi yang digunakan untuk menghitung nilai $\mathrm{IC}_{50} . \mathrm{IC}_{50}$ merupakan parameter konsentrasi yang ekuivalen memberikan $50 \%$ efek aktivitas antioksidan. Persamaan regresi diperoleh dari hubungan antara konsentrasi sampel dan persentase penghambat aktivitas radikal bebas. Nilai $\mathrm{IC}_{50}$ diperoleh dengan memasukkan $\mathrm{Y}=50$ sehingga nilai konsentrasi sampel (x) dapat dihitung. Quarsetin digunakan sebagai kontrol yang telah menghambat $50 \%$ radikal bebas. Tabel 3 berikut merupakan data nilai hasil uji aktivitas antioksidan dari masingmasing makroalga.

Tabel 3. Hasil Uji Antioksidan pada Masing- Masing Sampel Makro Alga

\begin{tabular}{clll}
\hline Sampel & Jenis Alga & \%Aktivitas Antioksidan & $\begin{array}{c}\text { IC50 } \\
\text { (mg/ml) }\end{array}$ \\
\hline S4 & Rhodophyta & $36,5783 \pm 0,0124$ & 8,324254 \\
\hline S24 & Rhodophyta & $59,2723 \pm 0,0679$ & 3,542056 \\
\hline S5 & Phaeophyta & $35,09402 \pm 0,0048$ & 23,065401 \\
\hline S9 & Phaeophyta & $60,90465 \pm 0,0494$ & 4,34048 \\
\hline
\end{tabular}

Dari Tabel 3 diatas, terlihat bahwa sampel S24 (Rhodophyta) memiliki aktivitas antioksidan yang paling baik dengan nilai IC50 sebesar 3,5421 mg/ml, dan paling buruk yaitu sampel S5 (Phaeophyta) memiliki nilai IC50 sebesar 23,0654 mg/ml. Semakin rendah nilai IC50, maka akan semakin baik aktivitas antioksidan dari sampel yang telah di uji (Ito et al., 2018) 
Secara statistik metode ANOVA, terdapat perbedaan yang tidak terlalu signifikan pada kadar rata-rata protein dari masing-masing sampel. Namun terdapat perbedaan yang signifikan pada aktivitas antioksidan dari masing masing sampel. Hal ini dapat dilihat pada Tabel 4 dan 5

Tabel 4. Analisa anova pada kadar protein total

\begin{tabular}{ccccc}
\hline Sampel & Rata-rata kadar protein & Beda absolut & LSD $=\mathbf{B N t}$ & Significan \\
\hline \multirow{3}{*}{ S4 } & 2,5675 & 2,547 & 4,028 & TS \\
\cline { 2 - 5 } & 2,5675 & 2,2888 & 4,028 & TS \\
\cline { 2 - 5 } & 2,5675 & 0,4898 & 4,028 & TS \\
\hline \multirow{3}{*}{ S24 } & 5,1146 & 2,547 & 4,028 & TS \\
\cline { 2 - 5 } & 5,1146 & 0,2583 & 4,028 & TS \\
\hline \multirow{3}{*}{ S5 } & 5,1146 & 3,0369 & 4,028 & TS \\
\cline { 2 - 5 } & 4,8563 & 2,2888 & 4,028 & TS \\
\hline \multirow{3}{*}{ S9 } & 4,8563 & 0,2583 & 4,028 & TS \\
\cline { 2 - 5 } & 4,8563 & 2,7786 & 4,028 & TS \\
\cline { 2 - 5 } & 2,0777 & 0,4898 & 4,028 & TS \\
\hline
\end{tabular}

Tabel 5. Analisa anova pada \%aktivitas antioksidan

\begin{tabular}{ccccl}
\hline Sampel & $\begin{array}{c}\text { Rata-rata \% aktivitas } \\
\text { antioksidan }\end{array}$ & Beda absolut & LSD =BNt & Sign \\
\hline \multirow{3}{*}{ S4 } & 36,578323 & 22,694 & 0,471158 & $\mathrm{~S}$ \\
\cline { 2 - 4 } & 36,578323 & 1,4843 & 0,471158 & $\mathrm{~S}$ \\
\hline \multirow{3}{*}{ S24 } & 36,57832 & 24,326 & 0,471158 & $\mathrm{~S}$ \\
\cline { 2 - 5 } & 59,272283 & 22,694 & 0,471158 & $\mathrm{~S}$ \\
\cline { 2 - 5 } & 59,272283 & 24,178 & 0,471158 & $\mathrm{~S}$ \\
\hline \multirow{3}{*}{ S5 } & 59,272283 & 1,6323 & 0,471158 & $\mathrm{~S}$ \\
\cline { 2 - 5 } & 35,094018 & 1,4843 & 0,471158 & $\mathrm{~S}$ \\
\hline \multirow{3}{*}{ S9 } & 35,094018 & 24,178 & 0,471158 & $\mathrm{~S}$ \\
\cline { 2 - 5 } & 35,094018 & 25,810 & 0,471158 & $\mathrm{~S}$ \\
\cline { 2 - 5 } & 60,904649 & 24,326 & 0,471158 & $\mathrm{~S}$ \\
\hline & 60,904649 & 1,6323 & 0,471158 & $\mathrm{~S}$ \\
\hline
\end{tabular}

Ket : Sign= Significant LSD = least signficance different; $\mathrm{BNt}=$ beda nyata terkecil;

$\mathrm{TS}=$ tidak signifikan; $\mathrm{S}=$ signifikan

\section{KESIMPULAN}

Kesimpulan pada penelitian ini, dibandingkan alga cokelat (Phaeophyta) kadar protein alga merah lebih tinggi yaitu sebesar $5,115 \pm 0.126 \%$ sedangkan kadar protein yang berasal dari alga cokelat hanya sebesar $2,078 \pm 0.505 \%$. Nilai aktivitas antioksidan yang lebih baik adalah alga merah $a$ ) yaitu dengan nilai $\mathrm{IC}_{50}$ sebesar $3,5421 \mathrm{mg} / \mathrm{ml}$, sedangkan alga cokelat memiliki aktivitas antioksidan yang kurang baik dengan nilai $\mathrm{IC}_{50}$ sebesar $23,0654 \mathrm{mg} / \mathrm{ml}$. 


\section{DAFTAR PUSTAKA}

[1] Amarowicz, R., Pegg, R. B., Rahimi-Moghaddam, P., Barl, B., \& Weil, J. A. (2004). Free-radical scavenging capacity and antioxidant activity of selected plant species from the Canadian prairies. Food Chemistry, 84(4), 551-562. https://doi.org/10.1016/S0308-8146(03)00278-4

[2] Dang, T. T., Bowyer, M. C., Van Altena, I. A., \& Scarlett, C. J. (2017). Comparison of chemical profile and antioxidant properties of the brown algae. International Journal of Food Science \& Technology, 174181. https://doi.org/10.1111/ijfs.13571

[3] Ito, M., Koba, K., Hikihara, R., Ishimaru, M., Shibata, T., Hatate, H., \& Tanaka, R. (2018). Analysis of functional components and radical scavenging activity of 21 algae species collected from the Japanese coast. Food Chemistry, 255(January), 147-156. https://doi.org/10.1016/j.foodchem.2018.02.070

[4] Liu, J., Jin, Y., Lin, S., Jones, G. S., \& Chen, F. (2015). Purification and identification of novel antioxidant peptides from egg white protein and their antioxidant activities. Food Chemistry, 175, 258266. https://doi.org/10.1016/j.foodchem.2014.11.142

[5] Suparmi, \& Sahri, A. (2009). Mengenal Potensi Rumput Laut: Kajian Pemanfaatan Sumber Daya Rumput Laut Dari Aspek Industri Dan Kesehatan. Sultan Agung, XLIV(118), 95-116.

[6] Wang, R., Xiao, H., Wang, Y., Zhou, W., \& Tang, X. (2007). Effects of three macroalgae, Ulva linza (Chlorophyta), Corallina pilulifera (Rhodophyta) and Sargassum thunbergii (Phaeophyta) on the growth of the red tide microalga Prorocentrum donghaiense under laboratory conditions. Journal of Sea Research, 58(3), 189-197. https://doi.org/10.1016/j.seares.2007.03.002 